\title{
GENEALOGI WACANA FOUCAULT TERHADAP KUMPULAN CERPEN "PROTES” KARYA PUTU WIJAYA
}

\author{
oleh \\ Evi Marlina Harahap (evimarlinaharahap@gmail.com) \\ Ilmu Sastra, Fakultas Ilmu Budaya, Universitas Gadjah Mada
}

\begin{abstract}
ABSTRAK-Tulisan ini bertujuan untuk memberikan analisis karya sastra dari buku kumpulan cerpen "Protes" (1994) milik Putu Wijaya melalui perspektif wacana kuasa Michel Foucault. Metode yang digunakan adalah metode genealogi wacana Foucault. Analisis secara genealogis berusaha membangun dan mempertahankan singularitas peristiwa, meninggalkan peristiwa spektakuler untuk peristiwa sepele, serta melihat keseluruhan rentang fenomena yang sering ditolak sebagai sejarah. Cerpen yang dianalisis adalah "Sampah”, “Teror", "Anjing (I)”, dan "Mimpi". Berdasarkan empat cerpen yang dianalisis, semua mewacanakan permasalahan moral. Unsur yang didiamkan adalah institusi ataupun subjek yang menjalankan kekuasaan. Selain itu, dalam empat cerpen yang dianalisis, semuanya mengandung alat-alat yang mendukung strategi kekuasaan. Dengan demikian, ada kekuasaan di dalamnya. Kekuasaan itu dijadikan sebagai latar belakang cerpen untuk menyampaikan wacana Putu Wijaya mengenai moralitas.
\end{abstract}

Kata Kunci: Genealogi, wacana, Foucault, cerpen, Putu Wijaya

\section{A. PENDAHULUAN}

Wacana merupakan instrumen utama yang digunakan untuk menyampaikan sesuatu baik itu dalam percakapan dua arah maupun satu arah. Persoalan wacana kerap dianggap hanya bagian dari pembelajaran linguistic semata. Sesungguhnya apa yang ada di balik wacana lebih dari sekadar materi pokok dalam kajian linguistic. Wacana menyimpan persoalan pemiliknya. Sebab hanya melalui wacana seseorang bisa mengeluarkan apa yang ada di dalam pikirannya. Bagaimanapun seorang pengguna wacana mempermainkan wacananya, akan selalu ada celah untuk membongkar kedok aslinya. Tentu saja wacana tidak hanya dipakai untuk mengkamuflasekan kedok yang sebenarnya.
Jika mengacu pada Foucault, wacana adalah instrumen untuk mendapat kekuasaan.

Wacana jugalah yang menjadi instrumen pengarang untuk menyampaikan aspirasinya. Seringkali pengarang karya sastra serius melika-likukan wacananya sehingga pembaca kadang sulit untuk memahaminya. Pengarang yang demikian tentu memiliki motif tertentu. Di sinilah tugas peneliti sastra melakukan analisisnya.

Putu Wijaya adalah salah satu pengarang yang memiliki kepedulian besar terhadap bangsa kita, Indonesia. Tulisantulisannya, terutama pada era 80 -an banyak sekali berisi kritik terhadap fenomena pada masa itu. Namun, mengingat era 80-an masih dikuasai oleh Orde Baru di mana penerbitkan karya sastra dilakukan dengan ketat. Pemerintah pada masa itu tidak segan- 
segan membredel dan memaksa menghentikan penerbitan terhadap karya yang dianggap mengganggu elektabilitas pemerintah. Maka, Putu yang juga banyak menulis pada masa itu tentu melika-likukan wacananya. Ia tidak secara langsung menyatakan aspirasinya. Dengan demikian, wacana yang dimiliki oleh Putu sangat menarik untuk dianalisis.

Setelah lama pengetahuan yang bersifat normatif melajuri setiap bidang objek, muncul suatu bentuk pemikiran baru yang menempatkan diri dari hal-hal yang bersifat normatif. Dalam kajian humaniora, objek kajian berada dalam tataran masyarakat modern. Michel Foucault adalah satu dari sekian banyak pemikir yang meneliti masyarakat modern. Penelitiannya sebagai akademisi tidak dapat dikatakan tetap. Sebelumnya ia adalah pengikut setia Marx hingga menjadi sangat anti terhadap pemikiran Marx. Tulisan-tulisannya juga sulit untuk dimasukkan dalam kategori tertentu. Tidak seperti Levi Strauss misalnya yang merupakan seorang antropologis, Freud yang merupakan psikoanalisis, atau Max Weber yang merupakan sosiologis. Namun, satu hal yang dapat dikatakan, bahwa semua tulisan-tulisan Foucault mengindikasikan adanya suatu bentuk kekuasaan.

Foucault mengembangkan beberapa konsep yang baru (meski dengan menggunakan istilah yang sudah dikenal sebelumnya), yang mendukung adanya praktik-praktik kekuasaan itu. Konsepkonsep itu tidak terbatas penggunaannya sehingga bisa juga digunakan dalam penelitian sastra. Meski konsep-konsep itu belum begitu populer di Indonesia hingga memasuki abad 20, kehadirannya sendiri sudah ditemukan dalam karya sastra Indonesia, yaitu dalam kumpulan cerpen Protes karya Putu Wijaya (1994).

Namun, untuk menemukan apa wacana yang terkandung dalam kumpulan cerpen Protes, perlu dianalisis dengan menggunakan metode pendekatan tertentu. Dalam tulisan ini akan digunakan pendekatan genealogis yang dirumuskan oleh Foucault tetapi dikembangkan oleh pengikutnya (Foucauldian), salah satunya adalah tulisan Jean Carabine dalam buku Discourse As Data: A Guide for Analysis (2001).

Sebelum memasuki arena pembahasan terhadap cerpen, akan disajikan sedikit tentang konsep-konsep Foucault. Semua konsep ini saling terhubung dan nantinya akan memudahkan analisis terhadap cerpen. Dari beberapa cerpen yang ditulis dalam buku Protes, penulis memilih empat cerpen sebagai objek yang dianalisis yaitu cerpen "Sampah" (1987), “Teror" (1984), “Anjing (1)" (1992), dan "Mimpi" (1990).

\section{a. Foucault Dan Strategi Kekuasaan}

Foucault mengawali penelitiannya dengan asumsi bahwa di dalam masyarakat ada individu yang berdisiplin yang tidak hanya dilakukan oleh institusi represif (polisi, rumah sakit), tetapi juga dalam interaksi masyarakat dan semua bentuk aktivitas sosial. Haryatmoko (2016: 9) bahkan menyatakan bahwa penelitian Foucault tentang subjek modern melalui bentuk-bentuk pengetahuan, praktik wacana terfokus pada kekuasaan-pengetahuan. Kekuasaan dan pengetahuan saling terkait tidak lepas dari pengaruh pemikiran 
Nietzsche bahwa keinginan untuk mengetahui kebenaran adalah indikasi akan keinginan untuk berkuasa.

Kekuasaan menurut Foucault bukanlah berupa kekerasan seperti yang diutarakan Machiavelli, represi yang diutarakan Freud, ataupun dominasi yang diutarakan Marx. Kekuasaan merupakan strategi kompleks yang hidup di tengah masyarakat, sehingga ia bukanlah sesuatu yang dimiliki melainkan sesuatu yang beroperasi. Kekuasaan itu ada di manamana, menyebar dalam hubungan-hubungan masyarakat. Pendapat ini juga telah diutarakan oleh beberapa akademisi yang membaca tulisan Foucault seperti Simon During (1992), Madan Sarup (1993), Petrus Sunu Hardiyanta (1997), Sara Mills (2003), dan Haryatmoko (2016).

Kekuasaan yang dirumuskan Foucault selalu disandingkan dengan istilah pengetahuan. Pengetahuan menurut Foucault memiliki artian yang luas, yaitu pengetahuan terhadap subjek yang biasanya diklaim subjektif dan pengetahuan ilmiah yang biasanya diklaim objektif. During (1992 : 92) menyatakan pengetahuan menurut Foucault adalah apa yang dikatakan dan apa yang berupa divisi internal dalam sejarah. Divisi internal di sini adalah perangkatperangkat yang menyusunnya. Jadi, pengetahuan bukanlah suatu kode, konvensi, atau rasionalisasi. Ia tidak bisa dinilai dari kriteria-kriteria itu. Sarup (2003: 127) menyatakan dengan frontal bahwa tanpa pengetahuan, kekuasaan tidak mungkin dijalankan bahwa pengetahuan tidak mungkin tidak melahirkan kekuasaan. Hal ini diasumsikannya sebab tulisan Foucault sangat dipengaruhi perspektif Nietzsche yang melihat klaim kebenaran (yang diasosiasikan dengan pengetahuan) sebagai produk kehendak untuk berkuasa. Hardiyanta (1997: 162) melihat pengetahuan Foucault telah merumuskan pengetahuan dari cara yang paling mendasar, bahwa pengetahuan berisi informasi mengenai suatu tubuh sehingga memudahkan penanaman kekuasaan. Pengetahuan menjadi jembatan tentang bagaimana suatu tubuh dipahami, dikuasai, dan dihukum. Mills (2003: 69) berpendapat bahwa Foucault menggambarkan pengetahuan sebagai suatu konjungsi terhadap relasi kekuasaan dan pencarian informasi. Menurutnya, apa yang diempasiskan oleh Foucault tentang pengetahuan adalah berupa bagian integral dari jalan meraih kekuasaan, bahwa produksi pengetahuan adalah salah satu yang klaim kekuasaan. Di mana ada ketidakseimbangan relasi kekuasaan di antara sekumpulan orang atau di antara institusi, di sana ada produksi pengetahuan. Bagi Haryatmoko (2016: 16), Foucault mendefenisikan strategi kekuasaan sebagai kehendak untuk mengetahui. Selain itu, Foucault menggambarkan kekuasaan sebagai sesuatu yang menghasilkan bidangbidang objek dan ritus-ritus kebenaran. Individu dan pengetahuan melanjutkan produksi itu. Kriteria keilmiahan menjadi ukuran kebenaran. Hal itu pada gilirannya akan membentu individu sehingga kekuasaan tidak bisa dipisahkan dari pengetahuan.

Kriteria keilmiahan Foucault yang dijelaskan oleh Haryatmoko diwadahi oleh suatu ritus tertentu yang dianggap benar, baik terlihat seperti institusi, tulisan, dsb maupun tidak seperti hukum, sejarah, 
wacana, dsb. Ritus ini dinamakan aparatus. Sarup (2003: 110) menyatakan aparatus adalah elemen-elemen yang terdiri dari strategi pola-pola hubungan kekuasaan yang mendukung dan didukung berbagai jenis pengetahuan.

Untuk menciptakan kriteria keilmiahan, dibutuhkan suatu pengantar yang dapat disalurkan kepada masyarakat itu. Wacana adalah pengantar yang diperlukan guna tersebarnya pernyataan ilmiah yang diyakini sebagai ritus-ritus kebenaran. Wacana tersebar melalui aparatus yang turut mengubah konstelasi sosial. Oleh karena itu, wacana harus terlihat seobjektif mungkin agar mendekati kriteria keilimiahan. Maka, tidak heran kalau Haryatmoko (2016: 17) berpendapat bahwa masyarakat berusaha menyalurkan, mengontrol, dan mengatur wacana mereka agar sesuai dengan tuntutan ilmiah. Wacana menjadi alat untuk menunjukkan kekuasaan. Foucault dalam salah satu kuliahnya di college de France sejak tahun 1981 hingga 1982 telah melibatkan budaya dalam perhatiannya. Foucault (2005: 179) menyatakan bahwa dalam kebudayaan adalah organisasi hierarkis dari nilai-nilai. Nilai-nilai itu diungkapkan, bisa juga diputarbalikkan dengan wacana yang terlihat objektif sebagai proses seleksi dan pengecualian.

Selain beberapa konsep di atas, ada satu hal lagi yang berupa strategi kekuasaan. Hal itu menurut Foucault adalah tubuh. Tubuh adalah tempat kuasa untuk menghukum. Foucault melakukan penelitian tentang tubuh secara mendalam dalam The History of Sexuality hingga menghasilkan beberapa volume. Ia memulai penjelasannya dengan bagaimana tubuh dilihat pada masa Romawi berkuasa, kemudian memasuki masa Victoria, hingga bagaimana tubuh dipandang dalam masyarakat modern masa kini. Hardiyanta bahkan secara spesifik menjabarkan bahasan tentang tubuh dalam bukunya Disiplin Tubuh. Di dalam buku tersebut Hardiyanta (1997) melihat bagaimana Foucault mendeskripsikan kekuasaan sejak dulu dipotretkan sebagai bentuk hukuman terhadap tubuh. Mulai dari hukuman dengan tubuh yang dihancurkan hingga hukuman yang tidak lagi menyentuh tubuh. Mills (2003: 81) mengungkap bahwa tubuh menurut Foucault harus dilihat sebagai fokus dari diciptakannya wacana. Tubuh adalah wadah di mana wacana diciptakan dan digaungkan. Itu sebabnya, bahasan tubuh menurut Foucault memiliki arti yang luas mulai dari kaitannya dengan individu hingga pada negara.

Dari tubuh kekuasaan dilimpahkan. Tidak hanya tubuh individu, tetapi juga tubuh sosial. Dalam buku Dicipline and Punish, Foucault melihat kekuasaan atas tubuh sosial itu dari model arsitektural panoptikon yang dirancang oleh J. Bentham terhadap sebuah penjara. Rancangan itu berupa didirikannya sebuah menara tinggi di tengah bangunan penjara, berhadapan dengan sel-sel penjara yang bisa dilihat dari luar tetapi tidak terlihat dari dalam. Bangunan ini membuat para narapidana senantiasa dipantau tanpa mengetahui siapa yang memantau. Foucault melihat hal ini sebagai bentuk disiplin baru terhadap individu. Ia menamakannya panoptikon. Efek utama sistem panoptikon menurut Hardiyanta (1997: 109) adalah bahwa kuasa berfungsi secara otomatis sebagai mesin 
yang menjamin kekuasaan tanpa melalui otoritas pribadi seperti raja. Sebutan 'mesin' terhadap panoptikon juga disampaikan oleh Sarup (2003: 118). Ia berpendapat bahwa panoptikon yang dirumuskan Foucault adalah mesin di mana setiap orang diawasi tanpa diketahui siapa pun. Haryatmoko (2016: 22) mengungkapkan bahwa Foucault melihat sistem panoptik adalah sebagai sistem di mana kekuasaan bersifat total dan tidak bersifat fisik. Haryatmoko (ibid, opcit) bahkan menyebutkan bahwa sistem panoptik ini adalah kekuasaan yang sempurna sebab aktualitas pelaksanaan kekuasaannya tidak diperlukan lagi tetapi efeknya dirasakan dalam jangka panjang. Sistem panoptikon ini memang bentuk kekuasaan yang sangat banyak diimplementasikan karena tidak memerlukan tindakan yang terus menerus tetapi membekas dengan mendalam dan permanen. Sebab, panoptikon membuat individu mengambil tanggung jawab terhadap dirinya sendiri, memasukkan relasi kuasa ke dalam dirinya, dan menjadi penakluk bagi dirinya sendiri. Haryatmoko (2016: 23) merumuskan tiga tujuan pembentukan masyarakat disipliner dari sistem panoptikon ini: dari segi ekonomi pelaksanaan lebih murah; dari segi politik kontrolnya tidak terlihat sehingga menjauhkan dari tindakan resistensi; terakhir dari segi pedagogi meningkatkan kepatuhan dan kegunaan seluruh unsur sistem. Ketiga tujuan ini memperlihatkan bahwa panoptikon menjangkau kehidupan paling intim tanpa bisa diketahui datang dari subjek tertentu.

\section{B. METODE PENELITIAN}

Genealogi adalah sebuah metode, bukan suatu konsep ataupun strategi kekuasaan. Foucault menggunakan kritik genealogis pada karya-karyanya setelah 1970an. Sebelumnya Foucault menggunakan kritik arkeologis. Foucault menggunakan istilah genealogi untuk merujuk pada kesatuan pengetahuan intelek dan ingataningatan lokal. Meskipun suatu metodologi, genealogi mendapatkan tempat di antara para pembaca-pembaca kritis Foucault. Hingga saat ini, sebagian besar penelitian menggunakan metode genealogi ini, terutama dalam tataran critical discourse analytic (CDA), dengan atau tanpa menggunakan teori Foucault. Namun yang perlu diperhatikan adalah bahwa genealogi yang dipakai dalam penelitian-penelitian saat ini tidak lepas dari apa yang dimaksudkan oleh Foucault.

Sarup (2003: 101) memberi penjelasan mengenai bagaimana genealogi menurut Foucault. Menurutnya analisis secara genealogis berusaha membangun dan mempertahankan singularitas peristiwa, meninggalkan peristiwa spektakuler untuk peristiwa sepele, serta melihat keseluruhan rentang fenomena yang sering ditolak sebagai sejarah. Sarup juga menyatakan bahwa genealogi Foucault fokus pada pengetahuan lokal, diskontiniu, dan hal remeh yang kemudian akan disusun secara hierarkis atas nama pengetahuan. Ia melihat bahwa dalam tulisan Foucault sudah yang menggunakan metode genealogi tidak ada yang konstan, tidak ada esensi, dan tidak ada bentuk kontinuitas yang tidak terinteripusi.

Hardiyanta (1997: 14-16) melihat bahwa apa yang menjadi pusat perhatian genealogi adalah hubungan timbal balik antara sistem kebenaran dan mekanisme kuasa. Ia menyatakan bahwa melalui 
genealogi Foucault berusaha menghancur ilusi tentang identitas sehingga Hardiyanta berpendapat bahwa genealogi tidak mencari asal usul melainkan menemukan awal-awal pembentukan diskursus, menganalisis pluralitas secara factual, dan melepaskan diri dari ilusi tentang identitas. Dengan metode genealogis ini, Hardiyanta menyatakan Foucault telah merumuskan beberapa aturan umum untuk studi tentang kuasa: jangan studi tentang kuasa sebagai bentuk represi atau larangan, melainkan melihat juga efekefek positifnya; analisis kuasa dan tekhniknya harus dalam kerangka khusus, jangan direduksikan sebagai suatu konsekuensi hukum dan struktur sosial. Dari aturan-aturan itu Hardiyanta menyimpulkan bahwa genealogi Foucault tidak hanya menghubungkan sistem-sistem kebenaran dan strategi kuasa, tetapi juga menunjukkan bagaimana mengkonseptualisasikan pemahaman strategi kuasa dengan cara menambah suatu dimensi baru dalam penelitian relasi-relasi sosial.

Apa yang membuat genealogi memiliki urgensi di masa sekarang menurut During (1992: 123) adalah kebutuhan tertentu yang menginginkan bahwa suatu proyek penelitian yang ditulis saat ini dan sekarang mengungkapkan kelemahan dan hubungan historis yang dapat memberikan efek politik secara spesifik. Hal ini dapat menyalurkan suara yang dulunya tidak tersalurkan. Dengan demikian, genealogi menolak kelanjutan historis yang mencitrakan bentuk humanisme, yang tidak memperlihatkan realitas administrasi negara modern. Maka, tidak seperti sejarah yang berkelanjutan, genealogi menurut During telah berubah menjadi dunia sosial kontemporer.

Beberapa penjelasan mengenai genealogi Foucault memberikan pemahaman yang baik tentang bagaimana genealogi selama ini berbeda dari arti secara gramatis. Penjelasan-penjelasan tersebut juga memperlihatkan seberapa baik metode ini jika digunakan dalam penelitian humaniora. Hal ini membuat banyak Foucauldian merumuskan formula genealogi dalam kajian diskursus. Formula ini diupayakan sesuai dengan apa yang dimaksudkan Foucault. Jean Carabine telah merumuskan bagaimana analisis genealogi wacana dilakukan dalam buku Discourse As Data : A Guide for Analysis (2001). Adapun genealogi wacana Foucault dirumuskan Carabine (2001: 281) sebagai berikut:

O Pilihan topik.

O Penguasaan dan pendalaman data.

O Identifikasi tema.

O Kesalingterhubungan antar wacana.

O Identifikasi strategi wacana.

O Unsur-unsur yang absen dan diam.

O Perlawanan atau kontra wacana.

O Identifikasi dampak wacana dan hasil analisa.

O Konteks berupa latar belakang isu.

O Kontekstualisasi materi di dalam jaringan kekuasaan/pengetahuan periode itu

O Perhatikan keterbatasan penelitian, data, dan sumber.

Beberapa rumusan tersebut dipaparkan Carabine untuk meneliti laporan Komisi Poor Laws (1834) mengenai ibu single parent yang tidak menikah. Perbedaan objek penelitian akan memberikan beberapa perbedaan penelitian. 
Karena objek penelitian dalam tulisan ini adalah karya sastra berupa fiksi, tidak semua rumusan yang ditawarkan Carabine dapat dipergunakan dalam penelitian ini. Hal itu karena data pendukung atau laporan faktual tidak tertera dalam karya sastra yang diteliti. Maka, rumusan genealogi yang diadopsi hanya yang memiliki pengaruh signifikan terhadap penelitian. Adapun rumusan yang diambil adalah Identifikasi tema, kesalingterhubungan antar wacana,identifikasi strategi wacana, serta unsur-unsur yang absen dan diam.

\section{HASIL DAN PEMBAHASAN}

\section{Cerpen "Sampah"}

Tema yang diidentifikasi :degradasi moral, ketimpangan hukum.

Hal ini terlihat dari penggalan dialog dalam cerpen "Sampah" sebagai berikut:

"Wanita itu masuk ke daerah pembuangan sampah. Di belakangnya anak-anak dan para pemuda mengikuti. Wanita itu mengorek-ngorek, mencungkil-cungkil, dan membalik-balik seperti mencari sesuatu yang berharga. Salah satu anak berteriak. Ia menemukan pistol. Orangorang jadi gempar. Wanita itu menemukan cincin kawin. Wanita itu berhenti mencari. Di seluruh kota sampahsampah dibongkar. Salah seorang menemukan mayat wanita di balik timbunan sampah, yang koyak moyak oleh pistol."
"Wanita itu sudah hilang. Sopir keluar mobil dengan panik. Ia menanyakan di mana kantor polisi. Ia bergegas ke situ. Anak tukang rokok melihat sopir itu masuk ke dalam kantor, tetapi tak pernah keluar lagi selama-lamanya."

\section{Keterhubungan antar wacana:}

- Cerita tentang wanita yang mencari sesuatu di tempat sampah.

- Di tempat sampah ditemukan pistol.

- Wanita ditemukan telah tewas dengan luka dari pistol.

\section{Identifikasi strategi wacana:}

- Menyatakan seorang wanita yang mencari benda berharga di tempat sampah.

- Menyatakan beberapa anak dan pemuda yang menemukan berbagai benda berharga lainnya.

- Menunjukkan bagaimana tempat sampah akhirnya menarik perhatian orang-orang.

- Menunjukkan bagaimana sopir berakhir di kantor polisi.

\section{Unsur yang didiamkan:}

- Polisi. Institusi kepolisian diungkapkan namun perannya sendiri luput.

\section{Cerpen 'Teror'}

Tema yang diidentifikasi: kemiskinan, terkikisnya moral.

Hal ini terlihat dari penggalan dialog dalam cerpen "Teror" sebagai berikut:

\footnotetext{
"Ini duit. Lihat. Asal kamu bilang mau, ini langsung kamu ambil."

"Kehadiran orang itu dengan rezeki, sudah memancing rasa mualnya. Karena ia marah
} 
pada nasib yang menginjakinjaknya bertahun-tahun. Tapi marah saja tidak cukup, karena besok ia kembali hidup dengan perut keroncongan. Mungkinkah marah masih tetap ampuh mulut anakistrinya."

“ 'Kalau boleh saya pinjam, barang lima puluh ribu, bagaimana?" "

'Itu lima puluh juta'.

'Tapi saya hanya perlu lima puluh ribu.'

Orang itu menggelenggelengkan kepala. 'Kamu gila!'

Ujang tampak gugup. Tangannya gemetar memegang kelimapuluhan ribu itu. Matanya berkaca-kaca. 'Terima kasih banyak, Pak. Apa yang harus saya lakukan? Mana barang itu? Di mana harus saya letakkan?'"

\section{Keterhubungan antar wacana:}

- Seorang lelaki mencoba membujuk Ujang untuk melakukan pekerjaan keji dengan imbalan uang.

- Ujang bimbang antara uang dan prinsip.

- Ujang dikalahkan oleh ketidakberdayaannya.

Identifikasi strategi wacana:

- Menyatakan seorang lelaki yang menggunakan berbagai bentuk wacana untuk meyakinkan Ujang, menyerangnya dari sisi ekonomi.

- Menyatakan penolakan Ujang terhadap bujukan-bujukan.

- Mengungkapkan ketidakberdayaan Ujang menghadapi kenyataan hidupnya.

- Memperlihatkan Ujang yang kalah terhadap bujukan.

\section{Unsur yang didiamkan:}

- Majikan. Tidak disebutkan secara jelas mengapa ia menjadi target pembunuhan, apa dan bagaimana perannya.

- Lelaki. Tidak digambarkan dengan siapa ia bekerja ataukah ia bekerja sendiri. Apa dan bagaimana hubungannya dengan yang majikan Ujang.

\section{Cerpen 'Anjing (1)'}

Tema yang diidentifikasi :kerusakan moral, jatuhnya identitas manusia.

Hal ini terlihat dari penggalan dialog dalam cerpen "Anjing (1)" sebagai berikut:

"Betapa enaknya menjadi manusia. Bisa membentakbentak, memukul, mengikat anjing dan membawanya ke mana-mana. Bisa korupsi, punya simpanan puluhan bini. Dan yang paling hebat, bisa punya anjing beberapa ekor saja, maunya. Dari yang paling mini sampai yang paling besar, buas, dan mahal. Manusia bisa mandiri, bisa bebas, bisa menuntut, bisa jadi maling tanpa kena hukuman, bisa menggarap manusia lain, bisa menipu manusia lain dan tetap dihormati. Dan khususnya tak usah berhubungan dengan 
dokter hewan. Menggaji dokter hewan boleh!"

"Kalau mereka diikat, itu bukan karena dipasung, tetapi dilindungi. Kalau mereka dikurung, itu bukan dijajah tapi dimanjakan. Di samping itu, merasakan memerlukan kejujuran. Tidak akan mungkin merasakan kebahagiaan kalau tidak jujur. Alangkah nikmatnya menjadi anjing. Anjing tidak usah lagi berpikir karena manusia sudah berpikir untuk dia. Dan itu berarti manusia adalah budak anjing."

\section{Keterhubungan antar wacana:}

- Seekor anjing mengkhayal menjadi manusia.

- Ia melihat fenomena-fenomena pada manusia.

- Menjadi anjing ternyata lebih beruntung dari manusia.

\section{Identifikasi strategi wacana:}

- Menyatakan keirian seekor anjing kepada manusia.

Menyatakan berbagai kehidupan paling gelap yang dijalani manusia.

Membalikkan wacana mengenai manusia lebih baik dari anjing menjadi anjing lebih baik dari manusia.

Unsur yang didiamkan:

- Tokoh-tokoh dan institusi dalam kehidupan manusia yang digambarkan anjing.

\section{Cerpen'Mimpi'}

Tema yang diidentifikasi :menutupi kejelekan dengan mengkambinghitam kejelekan moral, mengutamakan kebutuhan di atas moral.

Hal ini terlihat dari penggalan dialog dalam cerpen "Mimpi" sebagai berikut:

" 'Memang kelihatannya tolol dan bodoh kalau kita masih bicara soal moral dan harga diri di Jakarta ini. Sementara orang berlomba-lomba menumpuk kekayaan. Tetapi kalau kita tidak mulai dari sekarang menegakkan sedikit demi sedikit harga diri kita, kita akan selamanya menjadi manusia tertindas. Apa gunanya kita berlimpahan uang, kalau perasaan kita tidak tentram karena merasa kita sudah melacurkan diri kita?',

“ 'Apa artinya kegagahan kalau tidak bisa makan?' "'

\section{Keterhubungan antar wacana:}

- Bapak mengumumkan kalau ia berhenti dari pekerjaannya karena tidak setuju dengan kejelekan moral di kantornya.

- Istri dan anak-anak marah dengan keputusan bapak.

- Bapak keras kepala kalau ia tidak akan pernah bekerja di tempatnya yang lama lagi. Yang membuat perkelahian tidak berhenti.

- Bapak berbisik pada istrinya kalau ia dipecat. Istrinya sudah mengetahui hal itu dari awal.

\section{Identifikasi strategi wacana:}

- Menyatakan bahwa bapak berhenti bekerja dan menyatakan alasan-alasannya.

- Mengungkapkan alasan-alasan itu dengan cara heroik. Mengkambinghitamkan perusahaan. 
- Memperlihatkan ekspresi berlebihan istri menanggapi keputusan bapak.

- Memperlihatkan anak yang lebih mempedulikan kebutuhan berupa materi daripada moralitas.

- Mengungkapkan bahwa bapak dan istri sama-sama telah berbohong sejak awal.

Unsur yang didiamkan:

- Perusahaan. Bagaimana kebenaran dari sisi perusahaan. Mengapa pihaknya memecat bapak.

\section{IMPLEMENTASI KONSEP BESAR FOUCAULT DALAM CERPEN- CERPEN PROTES}

\section{- Cerpen 'Sampah'}

Tubuh.

Dalam cerpen 'Sampah' terlihat bahwa bagaimana tubuh dihancurkan. Tubuh wanita yang mati dengan luka tembak memperlihatkan adanya penyiksaan di tubuhnya. Penyiksaan itu dari agen yang berkuasa sehingga melalui tubuh itu ia memperlihatkan kekuasaannya. Maka dalam hal ini, kekuasaan terlihat dari tubuh yang dihancurkan (mengacu pada kasus Damiens tentang tubuh yang dihancurkan).

- Cerpen 'Teror'

Panoptikon.

Dalam cerpen ini diperlihatkan gambaran Ujang yang sangat patuh mengerjakan tugasnya. Ia menolak melakukan apa yang tidak seharusnya ia lakukan. Ia juga menolak sogokan. Ia menerima uang sebagai pinjaman, bukan pemberian. Hal ini memperlihatkan bagaimana Ujang tetap melakukan pekerjaannya sebaik mungkin tanpa diawasi penuh oleh majikannya. Ujang seperti orang yang selalu diawasi sehingga dalam bekerja pun, ia tidak mau menyalahi. Pengawasan yang dilakukan tidak berkelanjutan memiliki efek yang berkelanjutan terhadap Ujang. Ia adalah pengawas bagi dirinya sendiri.

\section{- Cerpen 'Anjing (1)'}

Aparatus.

Dalam cerpen ini, berbagai aparatus muncul, yaitu dokter hewan, juri festival film, sejarah, sutradara. Aparatus-aparatus ini digambarkan sebagai pencetus wacana yang mengubah suatu keputusan sosial. Wacana yang dikeluarkan oleh dokter hewan bisa menentukan perlu tidaknya suatu ras anjing dibunuh. Wacana yang dikeluarkan juri festival film bisa membuat seorang artis meningkat atau menurun citranya. Wacana sejarah bisa mengubah konstelasi sosial yaitu jenis makanan (dalam cerpen). Wacana sutradara yang bisa mendikte sekaligus menanamkan pengaruh bagi siapapun anggota film.

- Cerpen 'Mimpi'

Kebudayaan.

Konsep ini muncul belakangan pada permulaan tahun 80an dalam bukunya The Hemeneutics of the Subjects (2005:179), menyatakan bahwa kebudayaan selalu memiliki nilai-nilai hierarkis. Nilai-nilai ini dipakai untuk mengeksklusifkan diri. Dalam cerpen, tokoh bapak menggunakan hierarki baik dan buruk antara ia dan perusahaan. Ia menggunakan nilai-nilai buruk untuk membentuk wacana kalau ia yang bernilai baik. Bapak telah mengeksklusifkan diri dari hierarki baik buruknya moral dalam perusahaannya sehingga wacana yang ingin disampaikannya adalah: saya orang yang baik sebab itu saya keluar dari perusahaan. 


\section{KESIMPULAN}

Wacana Putu Wijaya terungkap dari kerangka genealogi cerpen-cerpennya. Terlihat dari wacana-wacana yang ia susun, semua mengindikasikan adanya permasalahan moral. Pilihan kata yang digunakan juga cenderung frontal. Selain itu, berdasarkan empat cerpen yang dianalisis, semua mewacanakan hal yang sama: permasalahan moral. Wacanayang dikedepankan Putu Wijaya, adalah krisis moral. Bagaimana moral yang rusak itu tidak kunjung diperbaiki, tetapi justru dipertahankan dengan materi sebagai pengikatnya. Unsur yang didiamkan adalah institusi ataupun subjek yang menjalankan kekuasaan. Hal itu memperlihatkan keberpihakan Putu Wijaya terhadap para penderita kekuasaan, sebab wacana merekalah yang diangkap dalam cerpencerpennya di tengah wacana moralitas. Putu melihat kerusakan moral menjadi langgeng berkat para pemegang kekuasaan. Dengan demikian, dalam kumpulan cerpen Protes, wacana yang ingin disampaikan Putu Wijaya adalah sebuah protes mengenai moral itu sendiri.

Selain itu, dalam empat cerpen yang dianalisis, semuanya mengandung alat-alat yang mendukung strategi kekuasaan. Dengan demikian, ada kekuasaan di dalamnya. Kekuasaan itu dijadikan sebagai latar belakang cerpen untuk menyampaikan wacana Putu Wijaya mengenai moralitas. Itu sebabnya yang menjadi sorotan dalam cerpen-cerpen yang dianalisis adalah pihak yang digambarkan menjalankan kekuasaan di atas pihak yang dikuasai.

\section{DAFTAR PUSTAKA}

During, Simon. 1992. Foucault and

Literature: Towards A Genealogy of Writing. New York : Routledge.

Foucault. 2005. The Hermeneutics of The Subjects: Lectures at the College De France, 19811982. New York: Palgrave Macmillan.

Hardiyanta, Petrus Sunu. 1997. Disiplin Tubuh: Bengkel Individu Modern. Yogyakarta : LKS.

Haryatmoko. 2016. Membongkar Rezim Kepastian: Pemikiran Kritis Post-Strukturalis. Yogyakarta : Kanisius.

Mills, Sarah. 2003. Michel Foucault. New York : Routledge.

Sarup, Madan. 2003. Postrukturalisme dan Posmodernisme. Yogyakarta : Penerbit Jendela.

Wetherell, Margaret, et.all (ed). 2001. Discourse As Data : A Guide Analysis. London: Sage Publication.

Wijaya, Putu. 1994. Protes. Jakarta: Grafiti. 